\title{
Analisis Persepsi Konsumen dan Strategi Pemasaran Beras Analog (Analog rice)
}

\author{
Deviany Amanda Rizki \\ Departemen Manajemen, Fakultas Ekonomi dan Manajemen \\ Institut Pertanian Bogor \\ Kampus Dramaga Bogor 16680 \\ Jono M. Munandar \\ Departemen Manajemen, Fakultas Ekonomi dan Manajemen \\ Institut Pertanian Bogor \\ Kampus Dramaga Bogor 16680 \\ M. Syaefudin Andrianto \\ Departemen Manajemen, Fakultas Ekonomi dan Manajemen \\ Institut Pertanian Bogor \\ Kampus Dramaga Bogor 16680 \\ e-mail: syaefudinandri@gmail.com
}

\begin{abstract}
Analog rice is artificial ricewhose material is not from paddy, but it is made from a variety of local flour (corn, sago and shorgum). As a new product, Rice Analog require appropriate marketing strategies through analysis of consumer perception. This research purposes are to develop a marketing strategy through identification Analog Rice segmentation, targeting and positioning based on consumer perception. The analytical method used were crosstabs analysis, cluster analysis and biplot analysis with 73 respondent. Crosstabs result indicated that consumer characteristics (age, marital status, education, income and expenses of month), associated with their impression and interested to re-purchase. Cluster analysis was delivered into four market segments, the third target market are 31-40 years old, married, the level of income of IDR 4,500,001 to IDR 6,000,000. Biplot analysis deliver positioning for Analog Rice product therefore this rice offers "health benefits", "nutritive ingredients", and "safe to consumed". Keywords : Analog rice, consumer perceptions, marketing strategy, cluster analysis, biplot analysis.
\end{abstract}

\begin{abstract}
ABSTRAK
Beras Analog adalah beras buatan dengan bahan bukan berasal dari padi, tetapi terbuat dari berbagai tepung lokal (jagung, sagu dan shorgum). Sebagai produk baru, Beras Analog membutuhkan strategi pemasaran yang tepat melalu analisis persepsi konsumen. Tujuan dari penelitian ini adalah untuk menyusun strategi pemasaran Analog Beras melalui identifikasi segmentasi, targetting dan positioning berdasarkan persepsi konsumen. Metode analisis yang digunakan adalah analisis crosstabs, analisis klaster dan analisis biplot dengan sampel responden adalah 73 orang. Dari hasil crosstabs menunjukkan bahwa karakteristik konsumen (umur, status perkawinan, pendidikan, pendapatan dan pengeluaran bulan), berhubungan dengan kesan dan minat untuk melakukan pembelian ulang. Analisis Cluster memberikan empat segmen pasar dengan segmen pasar ke 3 yaitu berusia 31-40 tahun, menikah dengan tingkat pendaptan Rp 4.500.001-Rp 6.000.000. Analisis biplot memberikan positioning untuk produk Beras Analog, sehingga beras ini menawarkan "manfaat kesehatan", "bahan bernutrisi", dan aman untuk dikonsumsi.

Kata kunci: beras Analog, persepsi konsumen, strategi pemasaran, analisis cluster, analisis biplot.
\end{abstract}




\section{Pendahuluan}

Tingkat konsumsi beras masyarakat Indonesia pada 2011 tercatat mencapai $102 \mathrm{~kg}$ per kapita per tahun. Angka konsumsi beras ini paling tinggi dibandingkan tingkat konsumsi di negara lain seperti Korea $40 \mathrm{~kg}$ per kapita per tahun, Jepang $50 \mathrm{~kg}$ per kapita per tahun, Malaysia $80 \mathrm{~kg}$ per kapita per tahun dan Thailand 70 kilogram per kapita per tahun. Rata-rata konsumsi beras dunia hanya $60 \mathrm{~kg}$ per kapita per tahun (Tempo 2013). Dengan tingkat konsumsi beras yang tinggi, ketahanan pangan Indonesia sangat rawan terutama bila terjadi bencana sehingga produksi beras tidak sesuai target. Oleh karena itu perlu dilakukan diversifikasi pangan.

Perilaku masyarakat Indonesia bila belum makan nasi artinya belum makan sulit dirubah sehingga merubahnya membutuhkan strategi pentahapan. Salah satu strateginya adalah membuat beras tiruan dengan bahan selain dari padi (artificial rice). Konsumen masih menyimpan, mengolah dan memakan dalam bentuk beras tetapi bahan bakunya bukan dari padi. F-Technopark sebagai salah satu pusat penelitian di Institut Pertanian Bogor (IPB) telah mengembangkan invensi beras dengan bahan selain dari padi yang disebut dengan Beras Analog. Beras ini telah diujicoba dan sedang dikembangkan dalam skala pilot plant untuk dikembangkan lebih lanjut dalam skala industri. Manfaat beras ini dalam jangka panjang untuk mendiversifikasi makanan pokok. Beras ini sudah ada pada tahun 1969-an dengan nama beras TEKAD (keTelo, Kacang dan Djagung) tetapi gagal berkembang (Andrianto et al.,2013). Persepsi konsumen terhadap beras analog perlu dikaji agar beras analog sukses dipasarkan.

Beras analog IPB adalah beras buatan yang dibuat dari berbagai tepung lokal (umbiumbian, serealia, sagu) dengan menggunakan teknologi ekstrusi panas. Beras Analog dikembangkan oleh F-Technopark Fakultas Teknologi Pertanian IPB sebagai pangan alternatif yang sehat dan aman serta memiliki sifat fisik dan fungsional menyerupai beras konvensional. Dari segi kandungan gizi, selain sama-sama merupakan sumber karbohidrat, Beras Analog terbukti lebih sehat karena memiliki Indeks Glikemik yang lebih rendah dibandingkan beras konvensional. Dengan karakteristik produk yang memiliki bentuk butiran menyerupai beras dan dikonsumsi layaknya nasi serta mempunyai komposisi gizi sesuai kebutuhan, Beras Analog mempunyai prospek yang sangat baik sebagai produk substansi beras konvensional yang mendukung program diversifikasi pangan (Budijanto 2012).

Penjualan Beras Analog dilakukan sejak bulan November 2012 dengan sistem purchasing order di tiga lokasi yaitu Serambi Botani, Restoran Taman Koleksi dan Kantor Pemerintah Kota Depok, Jawa Barat. Dalam melakukan kegiatan pengembangan dan mensosialiasikan Beras Analog sebagai produk yang relatif baru, sampai saat ini F-Technopark IPB masih menemui hambatan dalam menembus pasar. Hal ini dapat dilihat pada Gambar 1, dimana penjualan Beras Analog sejak bulan November 2012 hingga bulan Januari 2013 mengalami peningkatan di satu lokasi yaitu Serambi Botani. Sedangkan pada lokasi lain yaitu pada Restoran Taman Koleksi penjualan masih relatif kecil yaitu $20 \mathrm{~kg}$ per bulan dengan tidak adanya peningkatan maupun penurunan penjualan selama 3 bulan terakhir serta penjualan pada Kantor Pemerintah Kota Depok yang berlangsung selama 2 bulan yaitu bulan NovemberDesember 2012. 


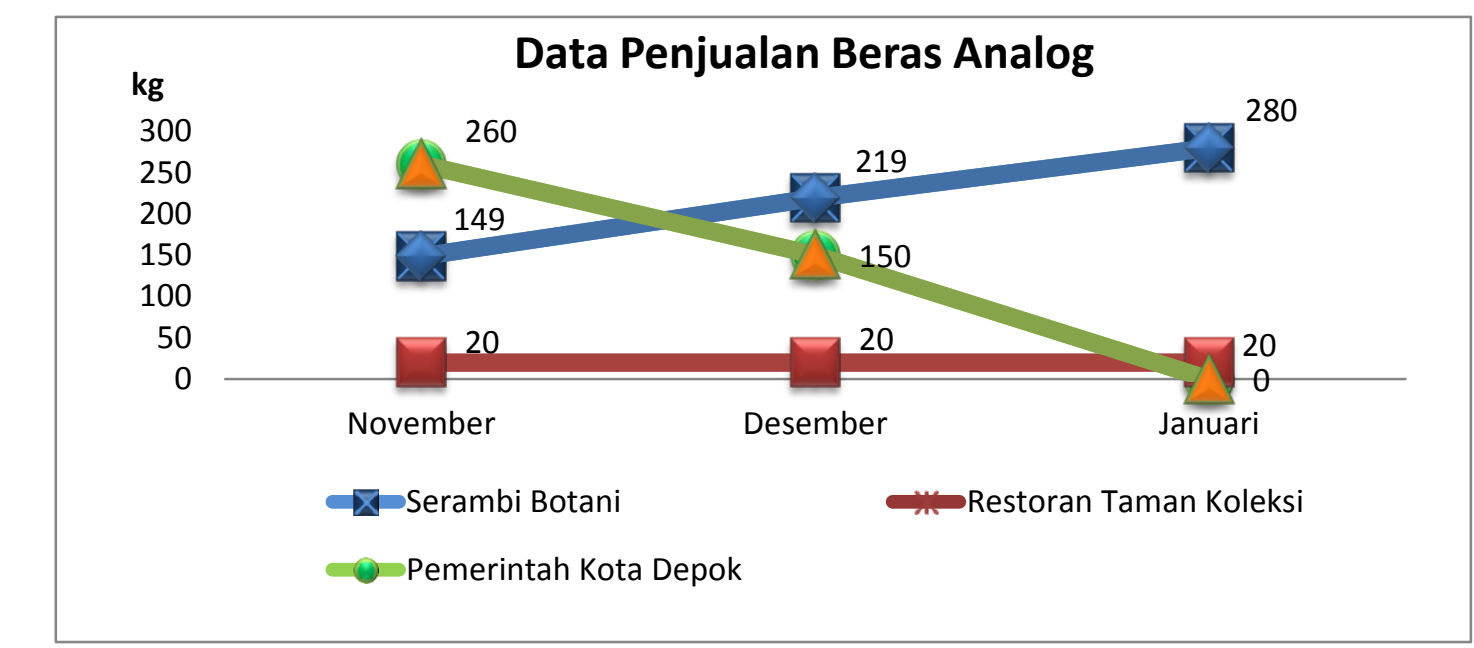

Gambar 1. Data penjualan Beras Analog per kilogram periode November-Januari 2012

(F-Technopark IPB 2013)

Berdasarkan uraian diatas, maka secara sistematis perumusan masalah dalam penelitian ini adalah sebagai berikut:

1. Bagaimana karateristik konsumen Beras Analog?

2. Bagaimana persepsi konsumen terhadap Beras Analog?

3. Strategi pemasaran apa yang dapat dilakukan bagi pemasaran produk Beras Analog melalui penetapan segmentation, targetting dan positioning?

Dalam penelitian ini, tujuan yang ingin dicapai adalah sebagai berikut :

1. Mengidentifikasi karateristik konsumen Beras Analog.

2. Menganalisis persepsi konsumen terhadap Beras Analog.

3. Merumuskan konsep strategi pemasaran produk Beras Analog melalui penetapan segmentation, targetting dan positioning.

Penelitian Andrianto et all. (2013) menyebutkan bahwa tingkat preferensi beras analog pada pasar remaja $67 \%$ menyatakan baik. Potensi pasar pada pasar remaja mencapai 11,5\% sebagai makanan alternatif. Kotler dan Armstrong (2008) membagi jenis-jenis penelitian pemasaran kedalam analisis peluang, penentuan target, perencanaan strategi, perancangan program dan pengukuran usaha pemasaran. Penelitian sebelumnya adalah analisis peluang sedangkan penelitian yang dilakukan adalah penelitina penentuan target pasar. Skema kerangka pemikiran penelitian ini dapat dilihat pada Gambar 2. 


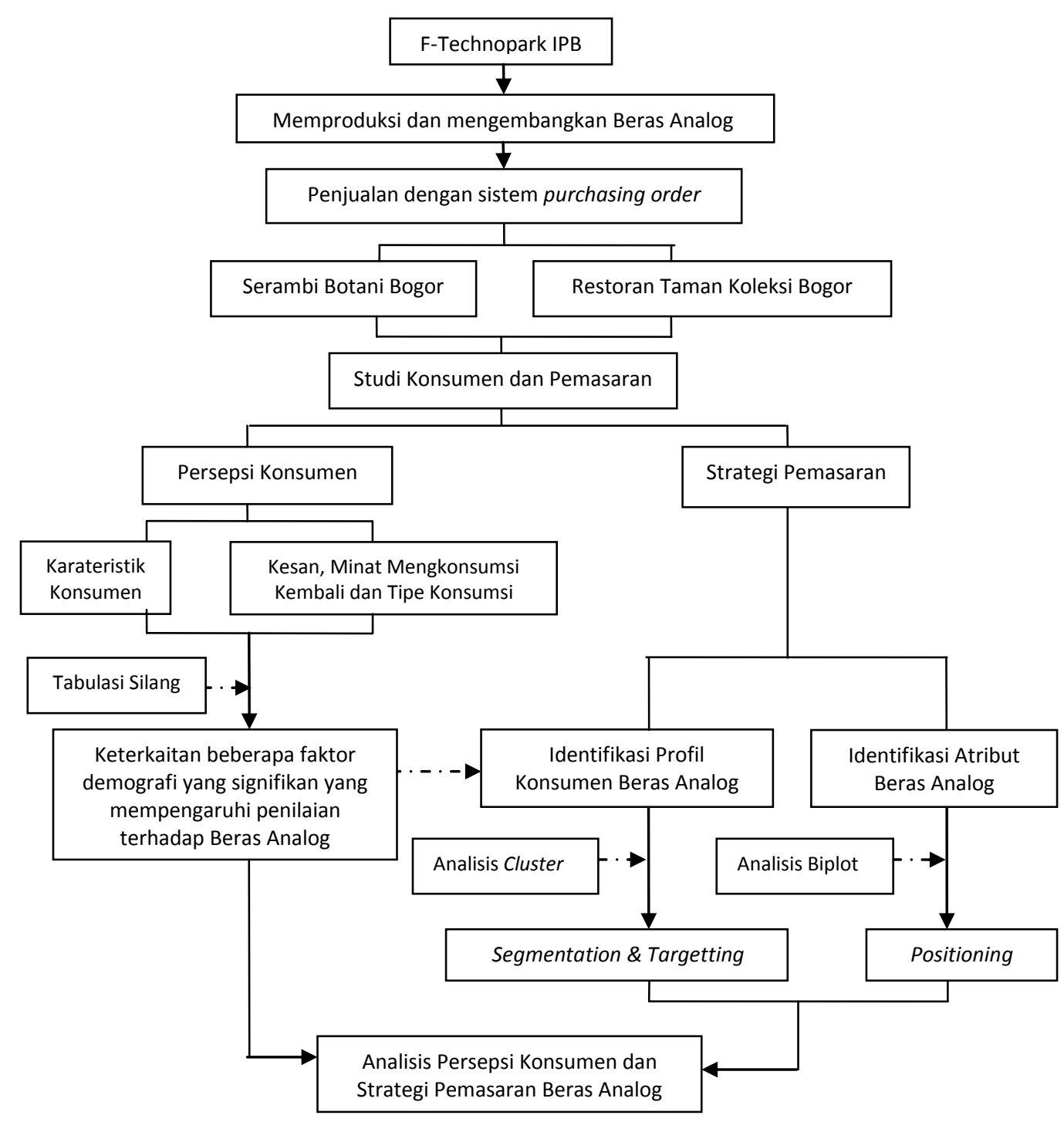

Gambar 2. Kerangka pemikiran

\section{Metode Penelitian}

Penelitian dilaksanakan di tiga tempat yaitu F-Technopark IPB, Serambi Botani Bogor dan Restoran Taman Koleksi. Pengumpulan data dalam penelitian ini meliputi data primer dan data sekunder. Data primer diperoleh melalui wawancara langsung dengan stakeholder F-Technopark IPB sedangkan survey dengan bantuan kuesioner dilakukan di dua outlet penjualan produk Beras Analog yang masih aktif yaitu Serambi Botani Bogor dan Restoran Taman Koleksi. Data sekunder diperoleh melalui penelusuran pustaka, dokumen, dan laporan instansi terkait yang relevan dengan topik penelitian

Dalam penelitian ini, jumlah sampel ditentukan dengan menggunakan rumus slovin dengan tingkat kepercayaan $90 \%$ sehingga nilai error (e) adalah $10 \%(0,1)$. Berdasarkan data populasi konsumen yang pernah membeli Beras Analog di Serambi Botani Bogor 
pada Maret 2013 adalah 186 orang, sedangkan data populasi konsumen yang pernah membeli produk Beras Analog di Restoran Taman Koleksi Bogor pada Maret 2013 adalah 88 orang. Sehingga total populasi yang pernah membeli produk Beras Analog sebesar 274 orang dengan asumsi populasi adalah konsumen yang melakukan pembelian sekali dalam sebulan. Maka jumlah sampel (n) minimum yang dibutuhkan adalah :

$$
\text { Jumlah sampel }=\frac{274}{1+\left(274^{*} 0.1^{2}\right)}=73,262 \approx 73 \text { orang }
$$

Pengambilan sampel menggunakan metode non-probability sampling dengan teknik convenience sampling dengan kriteria untuk responden yang dipilih adalah yang sudah pernah mengkonsumsi produk Beras Analog.

Pengolahan data dilakukan dengan menggunakan software Microsoft Excel 2007, IBM SPSS 19 dan Minitab 14. Kevalidan dan kesahihan data pada kuesioner menggunakan uji validitas dan uji reliabilitas, sedangkan analisis data menggunakan tabulasi silang, analisis cluster (analisis kelompok) dan analisis biplot. Adapun analisis yang digunakan dalam penelitian ini adalah sebagai berikut:

1. Uji Validitas

Uji validitas mengindikasikan apakah alat pengukuran yang ingin diukur sudah tepat atau belum (Umar 2000). Pada penelitian ini, uji validitas dilakukan terhadap 30 responden dan hasil penelitian dikatakan valid karena $r$ hitung setiap variabel pada pertanyaan tentang derajat kepentingan atribut Beras Analog lebih besar dari $r$ tabel yaitu 0,361 .

2. Uji Reliabilitas

Reliabilitas merupakan ukuran suatu kestabilan dan konsistensi responden dalam menjawab pertanyaan dalam kuesioner. Jika hasil pengukuran yang dilakukan berulang menghasilkan hasil yang relatif sama, pengukuran tersebut dianggap memiliki tingkat reliabilitas yang baik (Suliyanto 2005). Pada penelitian ini uji reliabilitas dilakukan terhadap 30 responden dan hasil penelitian dikatakan reliabel karena nilai Cronbach's Alpha setiap variabel pada pertanyaan tentang derajat kepentingan atribut Beras Analog bernilai lebih besar dari 0,60 yaitu 0,733.

3. Tabulasi Silang

Alat uji yang dipakai untuk tabulasi silang pada penelitiian ini adalah uji kebebasan (chi-square). Menurut Malhotra (2006) statistik uji chi square adalah statistik yang digunakan untuk menguji signifikansi statistik dari asosiasi yang diamati dalam sebuah tabulasi silang. Tabulasi silang pada penelitian ini digunakan untuk menguji keterkaitan antara karateristik konsumen, minat mengkonsumsi kembali dan tipe konsumsi dengan kesan terhadap Beras Analog. Tabulasi silang ini digunakan sebagai masukan dalam analisis persepsi konsumen dan penyusunan strategi pemasaran Beras Analog.

4. Analisis Cluster

Analisis Cluster (Analisis Kelompok) merupakan sebuah kelas teknik yang digunakan untuk mengklasifikasikan objek-ojek atau kasus-kasus menjadi kelompok-kelompok yang relative homogeny (kelompok) (Malhotra 2006). Pada penelitian ini, prosedur 
analisis cluster yang digunakan adalah Hierarki Cluster dikarenakan jumlah sampel yang relatif kecil serta data yang digunakan untuk analisis cluster dalam penelitian ini adalah jenis data dengan penggunaan skala berbeda. Menurut Simamora (2005), pada penggunaan skala yang berbeda, untuk memperoleh kesempatan yang sama setiap variabel perlu distandarisasi terlebih dahulu karena jika variabel tetap dalam bentuk aslinya, variabel-variabel yang memiliki standar deviasi paling besar akan tampil sebagai diferensiator utama, artinya proses segmentasi hanya akan dipengaruhi oleh variabel tertentu saja. Setelah dilakukan standarisasi data pada setiap variabel yang digunakan, barulah dilakukan analisis hierarki cluster. Tahap terakhir adalah mengklasifikasikan variabel-variabel menjadi kelompok-kelompok yang relative homogeny berdasarkan nilai yang sering muncul (modus). Analisis cluster diharapkan dapat menjawab segmentasi dan targeting melalui persepsi konsumen beras analog.

5. Analisis Biplot

Biplot adalah salah satu upaya menggambarkan data-data yang ada pada tabel ringkasan dalam grafik berdimensi dua (Sartono 2003 dalam Mattjik dan Sumertajaya 2011). Dalam penelitian ini, terdapat sepuluh atribut Beras Analog yang digunakan untuk mengetahui preferensi konsumen berdasarkan derajat kepentingan. Kesepuluh atribut tersebut diantaranya adalah manfaat kesehatan, rasa yang enak, tekstur yang pulen, harga terjangkau, kandungan nutrisi yang baik, warna menarik, keamanan dikonsumsi, kemasan yang menarik, promosi yang menarik dan daya tahan produk. Berdasarkan atribut-atribut tersebut, responden memilih preferensinya terhadap atribut-atribut yang mereka anggap sangat tidak penting (STP), tidak penting (TP), biasa saja (B), penting (P) dan sangat penting (SP). Dengan analisis Biplot, dapat dilihat atribut dominan menjadi atribut sangat penting dan penting.

\section{Hasil Dan Pembahasan}

III.1 Karakteristik konsumen

Karakteristik konsumen dapat dijadikan dasar dalam membuat segmentasi konsumen. Pada penelitian ini responden dikaji berdasarkan jenis kelamin, usia, status pernikahan, pendidikan terakhir, klasifikasi pekerjaan, status pekerjaan, klasifikasi profesi, rata-rata pendapatan per bulan, rata-rata pengeluaran per bulan dan hobi. Data karateristik responden yang diperoleh akan dinyatakan sebagai input dalam aspek persepsi konsumen dan proses penentuan segmentasi pasar.

a. Jenis Kelamin

Karakteristik konsumen Beras Analog berdasarkan jenis kelamin terdiri dari konsumen laki-laki $21,9 \%$ dan konsumen perempuan $78,1 \%$. Persentase tersebut menunjukkan bahwa konsumen Beras Analog didominasi oleh konsumen perempuan. Hal ini dipengaruhi oleh karakteristik konsumen perempuan yang cenderung lebih konsumtif dalam melakukan pembelian terhadap produk baru, khususnya produk yang digunakan sebagai bahan pangan.

b. Usia

Berdasarkan hasil penelitian, diketahui bahwa mayoritas konsumen Beras Analog didominasi oleh usia 31-40 tahun sebesar 35,6\%, kemudian berturut-turut 
responden yang berusia $21-30$ tahun sebanyak $27,4 \%$, usia $41-50$ tahun sebanyak 20,5\%, usia 51-60 tahun sebesar 6,8\%, usia kurang dari 20 tahun sebanyak 5,5\% dan usia lebih dari 60 tahun sebanyak 4,1\%.

c. Status Pernikahan

Dilihat dari status pernikahannya pada hasil pengolahan data responden, dapat diketahui bahwa sebagian besar konsumen Beras Analog dengan status menikah $61,6 \%$ dan belum menikah $38,4 \%$. Hal ini menyatakan bahwa mayoritas konsumen Beras Analog telah memiliki keluarga.

d. Tingkat Pendidikan

Berdasarkan tingkat pendidikan terakhir atau yang sedang dijalani, konsumen Beras Analog memiliki latar belakang pendidikan S1 42,5\%, diikuti pendidikan S2 20,5\%, Diploma 17,8\%, SMU/SMK 15,1\% dan S3 4,1\%. Dari data tersebut dapat diketahui bahwa konsumen Beras Analog didominasi oleh konsumen berpendidikan S1.

e. Klasifikasi Pekerjaan

Dilihat berdasarkan klasifikasi pekerjaan, responden paling banyak berstatus sebagai employee (pegawai) 42,5\%. Kemudian diikuti dengan klasifikasi pekerjaan terbanyak kedua yaitu unemployee (tidak bekerja) $28,8 \%$, business owner (pemilik usaha) $16,4 \%$, self employee (pekerja lepas) 9,6\%, dan investor (penanam modal) $2,7 \%$.

f. Status Pekerjaan

Berdasarkan hasil pengolahan data responden diperoleh data bahwa konsumen Beras Analog yang memiliki status pekerjaan sebagai pegawai swasta $24,7 \%$. Kemudian diikuti dengan status pekerjaan PNS 23,3\%, ibu rumah tangga 21,9\%, wiraswasta $17,8 \%$ dan mahasiswa/pelajar $12,3 \%$.

g. Profesi

Berdasarkan data yang diperoleh dapat diketahui bahwa mayoritas konsumen Beras Analog berprofesi sebagai Ibu rumah tangga sebanyak 19,2\%. Profesi dengan \%tase terendah adalah politikus $1,4 \%$.

h. Pendapatan Per Bulan

Berdasarkan hasil pengolahan data kuesioner penelitian diketahui bahwa responden Beras Analog mayoritas memiliki pendapatan per bulan sebesar Rp 4.500.001-Rp 6.000.000 sebanyak 30,1\%. Hal ini dikarenakan harga Beras Analog yang masih relatif mahal dibandingkan beras biasa (konvensional) pada umumnya, menyebabkan mayoritas konsumennya adalah yang berpendapatan di atas ratarata.

i. Pengeluaran Per Bulan

Besarnya pengeluaran per bulan sebagian besar konsumen Beras Analog adalah Rp 3.000.001-Rp 4.500.000 dengan persentase $28,8 \%$. Hal ini menunjukkan bahwa mayoritas konsumen tidak terlalu mempertimbangkan harga sebagai faktor utama untuk membeli produk Beras Analog.

j. Hobi

Berdasarkan klasifikasi hobi, responden Beras Analog memiliki hobi jalan-jalan dengan persentase terbesar 23,3\%. Disusul dengan hobi membaca $21,9 \%$, belanja $19,2 \%$, wisata kuliner $17,8 \%$, browsing $9,6 \%$ dan lainnya yang terdiri dari mendengarkan musik, menonton film dan berenang $8,2 \%$. 


\section{III.2 Persepsi konsumen}

\section{A. Kesan terhadap Beras Analog}

Perbedaan Beras Analog dengan beras biasa (konvensional) menimbulkan penilaian atau kesan yang berbeda-beda oleh masing-masing responden. Berdasarkan data yang diperoleh, dapat diketahui bahwa $35,6 \%$ responden memberikan kesan suka, kemudian 30,1\% responden memberikan kesan cukup, 19,2\% responden memberikan kesan kurang suka, 12,3\% memberikan kesan sangat suka, dan 2,7\% responden memberikan kesan tidak suka terhadap Beras Analog. Dari data tersebut, dapat diketahui bahwa konsumen yang menyukai Beras Analog masih dibawah 50\% yaitu sebesar $47,9 \%$ (kesan sangat suka dan suka). Hal ini menandakan bahwa belum terdapat penilaian positif terhadap kesan Beras Analog.

B. Penilaian terhadap Rasa, Warna, Aroma, Teksur dan Bentuk Beras Analog

Penilaian terhadap rasa, aroma, tekstur dan bentuk memiliki persentase terbesar terhadap penilaian suka dengan masing-masing persentase $43,8 \%$ untuk rasa, 32,9\% untuk aroma, 45,2\% untuk tekstur dan $49,3 \%$ untuk bentuk. Sedangkan persentase penilaian terbesar untuk warna adalah $31,5 \%$. Hal ini dikarenakan warna pada Beras Analog berbeda dengan warna beras biasa pada umumnya yaitu kuning kecoklatcoklatan yang berasal dari warna alami jagung.

C. Tipe Konsumsi Beras Analog

Menurut 57,5\% responden Beras Analog menyatakan produk Beras Analog cocok untuk dikonsumsi sebagai makanan selingan (kuliner), sementara 42,5\% berpendapat produk Beras Analog cocok untuk dikonsumsi sebagai makanan pokok. Berdasarkan data tersebut dapat diketahui bahwa keberadaan Beras Analog untuk saat ini belum mampu disetarakan dengan beras biasa (konvensional) yang dijadikan makanan pokok untuk mayoritas masyarakat Indonesia.

D. Bahan Kemasan Beras Analog

Dalam memilih kemasan Beras Analog, bahan kemasan yang paling banyak disukai oleh konsumen akhir untuk produk Beras Analog adalah bahan kemasan jenis Standing Pouch (Kemasan plastik yang dapat berdiri) yaitu 67,1\%. Kemasan Standing pouch banyak dipilih oleh konsumen dikarenakan Standing Pouch dianggap ekslusif atau jarang ditemui pada kemasan beras pada umumnya, sehingga memiliki daya jual yang tinggi.

E. Ukuran Kemasan Beras Analog

Ukuran kemasan yang banyak disukai responden untuk produk Beras Analog adalah ukuran 800 gram sebesar 39,7\%, disusul dengan ukuran $1 \mathrm{~kg}$ sebesar 34,2\%, 12,3\% untuk ukuran $2 \mathrm{~kg}, 9,6 \%$ untuk ukuran 0,5 kg dan $5 \mathrm{~kg}$ sebesar 4,1\%. Berdasarkan data tersebut dapat diketahui bahwa ukuran kemasan 800 gram dianggap sesuai untuk sebuah produk yang relatif baru.

F. Keterangan atau Informasi pada Kemasan Beras Analog

Pada kemasan yang sudah beredar di pasaran, keterangan atau informasi yang tertera pada kemasan Beras Analog yaitu komposisi bahan, nilai gizi, kode produksi, tanggal kadaluarsa, aturan penyajian, logo produsen, nama dan alamat konsumen serta merek dagang produk. Sedangkan kode seri SNI dan logo kehalalan produk belum dicantumkan pada kemasan yang beredar saat ini. Berdasarkan data dapat 
diketahui bahwa 15,1\% responden menyatakan pencantuman nilai gizi pada kemasan Beras Analog dianggap paling penting yang harus tertera pada kemasan.

G. Lokasi Pemasaran Beras Analog

Sebanyak $41,4 \%$ responden menyatakan lokasi yang tepat untuk memasarkan Beras Analog adalah pada pasar modern. Sebagian besar konsumen memilih pasar modern dikarenakan pasar modern mengalami pertumbuhan pesat setiap tahunnya dan jika Beras Analog dapat dipasarkan pada pasar modern, Beras Analog dapat bersaing dengan berbagai macam tipe beras yang sudah beredar di pasaran.

H. Bentuk Promosi Pemasaran Beras Analog

Bentuk promosi yang tepat yang diharapkan oleh responden untuk Beras Analog adalah melalui iklan televisi dengan persentase terbesar yaitu $21,7 \%$. Hal ini dikarenakan televisi merupakan bentuk media massa paling efektif karena televisi dapat menjangkau semua kalangan masyarakat.

I. Harga Beras Analog

persentase terbesar untuk harga Beras Analog per pack adalah Rp 23.000 ukuran 800 gram sebesar 37\%. Persentase terkecil adalah Rp 50.000 ukuran 2 kg sebesar $11 \%$.

J. Minat Mengkonsumsi Kembali

Setelah memberikan kesan dan penilaian terhadap Beras Analog, responden menyatakan pendapatnya tentang minat mengkonsumsi kembali Beras Analog. Hal ini dikarenakan mayoritas responden baru mengkonsumsi produk Beras Analog sebanyak satu kali. Berdasarkan data penelitian dapat diketahui bahwa 79,5\% responden menyatakan keinginannya untuk mengkonsumsi kembali Beras Analog, sedangkan 20,5\% responden menyatakan tidak.

\section{III.3 Tabulasi silang}

Nilai crosstabulation yang korelasinya berada kurang dari 0.1 maka dapat dinyatakan adanya korelasi atau hubungan pada variabel tersebut (Tabel 1).

Tabel 1. Ringkasan hasil uji tabulasi silang

\begin{tabular}{lccc}
\hline \multicolumn{1}{c}{ Variabel } & \multicolumn{2}{c}{ Chi Square } & Korelasi \\
\cline { 2 - 3 } & Value & Asy. Sig & \\
\hline Jenis Kelamin*Kesan & 3,097 & 0,542 & Tidak signifikan \\
Usia*Kesan & 28,665 & 0,095 & Signifikan \\
Status Pernikahan*Kesan & 8,054 & 0,090 & Signifikan \\
Pendidikan*Kesan & 24,213 & 0,085 & Signifikan \\
Klasifikasi Pekerjaan*Kesan & 14,907 & 0,531 & Tidak signifikan \\
Status Pekerjaan*Kesan & 20,440 & 0,201 & Tidak signifikan \\
Profesi*Kesan & 47,366 & 0,337 & Tidak signifikan \\
Pendapatan*Kesan & 28,879 & 0,025 & Signifikan \\
Pengeluaran*Kesan & 23,999 & 0,090 & Signifikan \\
Hobi*Kesan & 23,999 & 0,242 & Tidak signifikan \\
Kesan* Minat Mengkonsumsi kembali & 28,333 & 0,000 & Signifikan \\
Kesan* Tipe Konsumsi & 14,439 & 0,016 & Signifikan \\
\hline Sumber: Data Primer, & & &
\end{tabular}

Sumber: Data Primer, diolah (2013) 
A. Hubungan antara Usia dengan Kesan

Responden yang mempunyai kesan sangat suka terhadap Beras Analog lebih banyak berasal dari responden dengan kalangan usia 41-50 tahun yaitu 6.8\%. Konsumen pada usia ini biasanya akan lebih selektif dalam pemilihan konsumsi pangan yang lebih sehat, baik untuk dirinya sendiri maupun untuk konsumsi keluarganya.

Tabel 2. Hasil uji tabulasi silang antara usia dengan kesan

\begin{tabular}{lcccccc}
\hline \multicolumn{1}{c}{ Usia } & \multicolumn{5}{c}{ Kesan (\%) } & \multirow{2}{*}{$\begin{array}{c}\text { Total } \\
\text { (\%) }\end{array}$} \\
\cline { 2 - 6 } & Sangat Suka & Suka & Cukup & Kurang Suka & Tidak Suka & \\
\hline$<$ 20 tahun & 0 & 0 & 1,4 & 4,1 & 0 & 5,5 \\
21-30 tahun & 1,4 & 6,8 & 12,3 & 5,5 & 1,4 & 27,4 \\
31-40 tahun & 2,7 & 17,8 & 8,2 & 5,5 & 1,4 & 35,6 \\
$41-50$ tahun & 6,8 & 9,6 & 2,7 & 1,4 & 0 & 20,5 \\
$51-60$ tahun & 0 & 1,4 & 4,1 & 1,4 & 0 & 6,8 \\
$>60$ tahun & 1,4 & 0 & 1,4 & 1,4 & 0 & 4,1 \\
\hline Total & $\mathbf{1 2 , 3}$ & $\mathbf{5 , 6}$ & $\mathbf{3 0 , 1}$ & $\mathbf{1 9 , 2}$ & $\mathbf{2 , 7}$ & $\mathbf{1 0 0 , 0}$ \\
Chi Square & & & & & & $\mathbf{0 , 0 9 5}$ \\
\hline
\end{tabular}

Sumber: Data Primer, diolah (2013)

Pada output hasil uji Chi-Square (Tabel 2), nilai Asymp.Sig.(2-sided) menunjukkan angka 0,095 yang lebih kecil dari 0.10 yang menyatakan bahwa terdapat hubungan yang signifikan antara usia dengan kesan.

B. Hubungan antara Status Pernikahan dengan Kesan

Mayoritas responden yang mempunyai kesan sangat suka dan suka didominasi oleh responden yang sudah menikah yaitu $11 \%$ dan $24,7 \%$. Responden yang telah memiliki keluarga lebih selektif dalam pemilihan pangan pokok karena bertanggungjawab untuk memperhatikan konsumsi keluarganya sehari-hari. Sedangkan responden yang belum berkeluarga cenderung lebih fleksibel dalam pemilihan konsumsinya. Pada output hasil uji Chi-Square (Tabel 3), nilai Asymp.Sig.(2-sided) menunjukkan angka 0,090 yang lebih kecil dari 0,10. Sehingga terdapat hubungan antara karakteristik status pernikahan dengan kesan terhadap Beras Analog.

Tabel 3. Hasil uji tabulasi silang antara status pernikahan dengan kesan

\begin{tabular}{|c|c|c|c|c|c|c|}
\hline \multirow{2}{*}{$\begin{array}{c}\text { Status } \\
\text { Pernikahan }\end{array}$} & \multicolumn{5}{|c|}{ Kesan (\%) } & \multirow{2}{*}{$\begin{array}{c}\text { Total } \\
(\%)\end{array}$} \\
\hline & $\begin{array}{c}\text { Sangat } \\
\text { Suka }\end{array}$ & Suka & Cukup & $\begin{array}{c}\text { Kurang } \\
\text { Suka }\end{array}$ & Tidak Suka & \\
\hline Menikah & 11,0 & 24,7 & 15,1 & 8,2 & 2,7 & 61,6 \\
\hline Belum Menikah & 1,4 & 11,0 & 15,1 & 11,0 & 0 & 38,4 \\
\hline Total & 12,3 & 35,6 & 30,1 & 19,2 & 2,7 & 100,0 \\
\hline
\end{tabular}

Sumber: Data Primer, diolah (2013)

C. Hubungan antara Tingkat Pendidikan dengan Kesan

Persentase terbesar untuk kesan suka dimiliki oleh pendidikan tingkat S1 dengan persentase $17,8 \%$, sedangkan kesan tidak suka dimiliki oleh pendidikan SMU/SMK dengan persentase $2,7 \%$ (Tabel 4). 
Tabel 4. Hasil uji tabulasi silang antara tingkat pendidikan dengan kesan

\begin{tabular}{lcccccc}
\hline \multicolumn{1}{c}{ Pendidikan } & \multicolumn{3}{c}{ Kesan (\%) } & \multirow{2}{*}{$\begin{array}{c}\text { Total } \\
\text { (\%) }\end{array}$} \\
\cline { 2 - 5 } & $\begin{array}{c}\text { Sangat } \\
\text { Suka }\end{array}$ & Suka & Cukup & $\begin{array}{c}\text { Kurang } \\
\text { Suka }\end{array}$ & Tidak Suka & \\
\hline SMU/SMK & 1,4 & 2,7 & 5,5 & 2,7 & 2,7 & 15,1 \\
DIPLOMA & 0 & 6,8 & 6,8 & 4,1 & 0 & 17,8 \\
S1 & 2,7 & 17,8 & 13,7 & 8,2 & 0 & 42,5 \\
S2 & 6,8 & 6,8 & 2,7 & 4,1 & 0 & 20,5 \\
S3 & 1,4 & 1,4 & 1,4 & 0 & 0 & 4,1 \\
\hline Total & $\mathbf{1 2 , 3}$ & $\mathbf{3 5 , 6}$ & $\mathbf{3 0 , 1}$ & $\mathbf{1 9 , 2}$ & $\mathbf{2 , 7}$ & $\mathbf{1 0 0 , 0}$ \\
Chi Square & & & & & & $\mathbf{0 , 0 8 5}$ \\
\hline
\end{tabular}

Sumber: Data Primer, diolah (2013)

Hasil output uji Chi-Square menunjukkan bahwa terdapat hubungan antara tingkat pendidikan dengan kesan karena Nilai Asymp.Sig.(2-sided) pada output bernilai 0,085 yang lebih kecil dari taraf nyata yang digunakan $(0,085<0,10)$.

D. Hubungan antara Pendapatan dengan Kesan

Berdasarkan hasil tabulasi silang, persentase terbesar responden terhadap kesan sangat suka dan suka didominasi oleh responden yang memiliki rata-rata pendapatan antara Rp 4.500.001-Rp 6.000.000. Sedangkan kesan tidak suka dimiliki oleh responden yang memiliki rata-rata pendapatan 2,7\% (Tabel 5).

Tabel 5. Hasil uji tabulasi silang antara pendapatan dengan kesan

\begin{tabular}{lccccccc}
\hline \multicolumn{1}{c}{ Pendapatan } & \multicolumn{5}{c}{ Kesan (\%) } & $\begin{array}{c}\text { Total } \\
\text { (\%) }\end{array}$ \\
\cline { 2 - 6 } & $\begin{array}{c}\text { Sangat } \\
\text { Suka }\end{array}$ & Suka & Cukup & $\begin{array}{c}\text { Kurang } \\
\text { Suka }\end{array}$ & $\begin{array}{c}\text { Tidak } \\
\text { Suka }\end{array}$ & \\
\hline Rp 1.500.000 & 0 & 1,4 & 4,1 & 5,5 & 0 & 11,0 \\
Rp1.500.001-Rp3.000.000 & 1,4 & 5,5 & 8,2 & 2,7 & 2,7 & 20,5 \\
Rp 3.000.001-Rp 4.500.001 & 1,4 & 9,6 & 6,8 & 6,8 & 0 & 24,7 \\
Rp 4.500.001 - Rp 6.000.001 & 5,5 & 13,7 & 11,0 & 0 & 0 & 30,1 \\
>_Rp6.000.001 & 4,1 & 5,5 & 0 & 4,1 & 0 & 13,7 \\
\hline Total & $\mathbf{1 2 , 3}$ & $\mathbf{3 5 , 6}$ & $\mathbf{3 0 , 1}$ & $\mathbf{1 9 , 2}$ & $\mathbf{2 , 7}$ & $\mathbf{1 0 0 , 0}$ \\
Chi Square & & & & & & $\mathbf{0 , 0 2 5}$ \\
\hline
\end{tabular}

Sumber: Data Primer, diolah (2013)

Nilai Asymp.Sig pada output uji Chi-Square menunjukkan angka 0,025 yang lebih kecil dari taraf nyata yang digunakan. Hal ini menunjukkan bahwa semakin Besar pendapatan semakin besar persentase yang menyukai Beras Analog.

E. Hubungan antara Pengeluaran dengan Kesan

Berdasarkan hasil tabulasi silang, persentase terbesar responden terhadap kesan sangat suka dan suka didominasi oleh responden yang memiliki rata-rata pengeluaran Rp 3.000.001-Rp 4.500.000. Sedangkan kesan tidak suka dimiliki oleh responden yang memiliki rata-rata pengeluaran $\mathrm{Rp} 1.500 .001-\mathrm{Rp} 3.000 .000$ yaitu 2,7\% (Tabel 6). 
Tabel 6. Hasil uji tabulasi silang antara pengeluaran dengan kesan

\begin{tabular}{lcccccc}
\hline \multicolumn{1}{c}{ Pengeluaran } & \multicolumn{3}{c}{ Kesan (\%) } & $\begin{array}{c}\text { Total } \\
\text { (\%) }\end{array}$ \\
\cline { 2 - 5 } & $\begin{array}{c}\text { Sangat } \\
\text { Suka }\end{array}$ & Suka & Cukup & $\begin{array}{c}\text { Kurang } \\
\text { Suka }\end{array}$ & $\begin{array}{c}\text { Tidak } \\
\text { Suka }\end{array}$ \\
\hline$<$ Rp 1.500.000 & 0 & 2,7 & 5,5 & 5,5 & 0 & 13,7 \\
Rp 1.500.001 - Rp 3.000.000 & 1,4 & 6,8 & 11,0 & 4,1 & 2,7 & 26,0 \\
Rp 3.000.001-Rp 4.500.001 & 4,1 & 11,0 & 8,2 & 5,5 & 0 & 28,8 \\
Rp 4.500.001 - Rp 6.000.001 & 2,7 & 11,0 & 5,5 & 0 & 0 & 19,2 \\
>_Rp 6.000.001 & 4,1 & 4,1 & 0 & 4,1 & 0 & 12,3 \\
\hline Total & $\mathbf{2 , 3}$ & $\mathbf{5 , 6}$ & $\mathbf{3 0 , 1}$ & $\mathbf{1 9 , 2}$ & $\mathbf{2 , 7}$ & $\mathbf{1 0 0 , 0}$ \\
Chi Square & & & & & & $\mathbf{0 , 0 9 0}$ \\
\hline
\end{tabular}

Sumber: Data Primer, diolah (2013)

Nilai Asymp.Sig.(2-sided) menunjukkan angka 0,090 yang lebih kecil dari taraf nyata yang digunakan. Hal ini menunjukkan bahwa karakteristik pengeluaran berhubungan signfikan dengan kesan terhadap Beras Analog.

E. Hubungan antara Kesan dengan Minat Mengkonsumsi Kembali

Berdasarkan hasil tabulasi silang pada Tabel 7, kesan responden terhadap Beras Analog sangat menentukan minat mengkonsumsi kembali, hal ini dapat dilihat pada Tabel 7 yang menyatakan bahwa sebesar 12,3\% responden menyatakan sangat suka, 35,6\% menyatakan suka, 23,3\% menyatakan cukup suka, 8,2\% menyatakan suka, dengan sebanyak $79,5 \%$ menyatakan minat untuk mengkonsumsi kembali. Nilai Asymp.Sig.(2-sided) menunjukkan angka 0,000 yang lebih kecil dari taraf nyata yang menyatakan bahwa kesan terhadap Beras Analog berhubungan signfikan dengan minat mengkonsumsi kembali.

Tabel 7. Hasil uji tabulasi silang antara kesan dengan minat mengkonsumsi kembali

\begin{tabular}{lccc}
\hline \multirow{2}{*}{ Kesan } & \multicolumn{2}{c}{ Minat Mengkonsumsi Kembali (\%) } & Total (\%) \\
\cline { 2 - 3 } & Ya & Tidak & 12,3 \\
\hline Sangat Suka & 12,3 & 0 & 35,6 \\
Suka & 35,6 & 0 & 30,1 \\
Cukup Suka & 23,3 & 6,8 & 19,2 \\
Kurang Suka & 8,2 & 11,0 & 2,7 \\
Tidak Suka & 0 & 2,7 & $\mathbf{1 0 0 , 0}$ \\
\hline Total & $\mathbf{7 9 , 5}$ & $\mathbf{2 0 , 5}$ & $\mathbf{0 , 0 0 0}$ \\
\hline
\end{tabular}

Sumber: Data Primer, diolah (2013)

F. Hubungan antara Kesan dengan Tipe Konsumsi

Berdasarkan hasil tabulasi silang, kesan responden terhadap Beras Analog juga menentukan tipe konsumsi apa yang cocok untuk Beras Analog. Sebanyak 28,7\% konsumen yang menyukai Beras Analog (kesan sangat suka dan suka) menyatakan bahwa Beras Analog cocok untuk dikonsumsi sebagai makanan pokok. Sedangkan mayoritas konsumen yang menyatakan kesan cukup dan kurang suka dengan masing-masing 19,2\% dan 17,8\% menyatakan Beras Analog cocok untuk dikonsumsi sebagai makanan selingan (kuliner). Tabel 8 Nilai Asymp.Sig.(2-sided) menunjukkan angka 0,016 yang lebih kecil dari taraf nyata yang digunakan. Sehingga dapat diambil kesimpulan bahwa kesan terhadap Beras Analog berhubungan signfikan dengan tipe konsumsi Beras Analog. 
Tabel 8. Hasil uji tabulasi silang antara kesan dengan tipe konsumsi

\begin{tabular}{lccc}
\hline \multicolumn{1}{c}{ Kesan } & \multicolumn{2}{c}{ Tipe Konsumsi (\%) } & \multirow{2}{*}{ Total (\%) } \\
\cline { 2 - 3 } & Makanan Pokok & Makanan selingan (kuliner) & \\
\hline Sangat Suka & 8,2 & 4,1 & 12,3 \\
Suka & 20,5 & 15,1 & 35,6 \\
Cukup & 11,0 & 19,2 & 30,1 \\
Kurang Suka & 1,4 & 17,8 & 19,2 \\
Tidak Suka & 1,4 & 1,4 & 2,7 \\
\hline Total & $\mathbf{4 2 , 5}$ & $\mathbf{5 7 , 5}$ & $\mathbf{1 0 0 , 0}$ \\
Chi Square & & & $\mathbf{0 , 0 1 6}$ \\
\hline
\end{tabular}

Sumber: Data Primer, diolah (2013)

\section{III.4 Analisis cluster}

Penelitian ini menggunakan analisis cluster untuk menganalisis data yang diperoleh dari kuesioner yang disebarkan kepada 73 responden. Hasil dari analisis ini akan digunakan untuk menentukan segmentasi pasar Beras Analog yang merupakan bagian dari perencanaan strategi pemasaran. Segmentasi didasarkan atas karakteristik demografi konsumen yang signifikan berdasarkan hasil uji tabulasi silang yaitu usia, status pernikahan, tingkat pendidikan, pendapatan dan pengeluaran serta kesan terhadap Beras Analog. Prosedur analisis cluster yang digunakan pada penelitian ini adalah dengan menggunakan metode hierarki. Analisis Hierarki Cluster digunakan untuk sampel < 100. Variabel kuesioner penelitian dalam karakteristik demografi dan kesan terhadap Beras Analog merupakan kombinasi variabel nominal, ordinal, interval dan rasio. Untuk melakukan analisis cluster, variabel-variabel tersebut perlu dilakukan standarisasi data terlebih dahulu. Setelah dilakukan standarisasi data, tahap selanjutnya adalah mengelompokkan variabel-variabel tersebut dalam hierarki cluster. Untuk melakukan interpretasi terhadap cluster yang terbentuk dapat dilihat pada output dendogram di bawah ini (Gambar 3). 


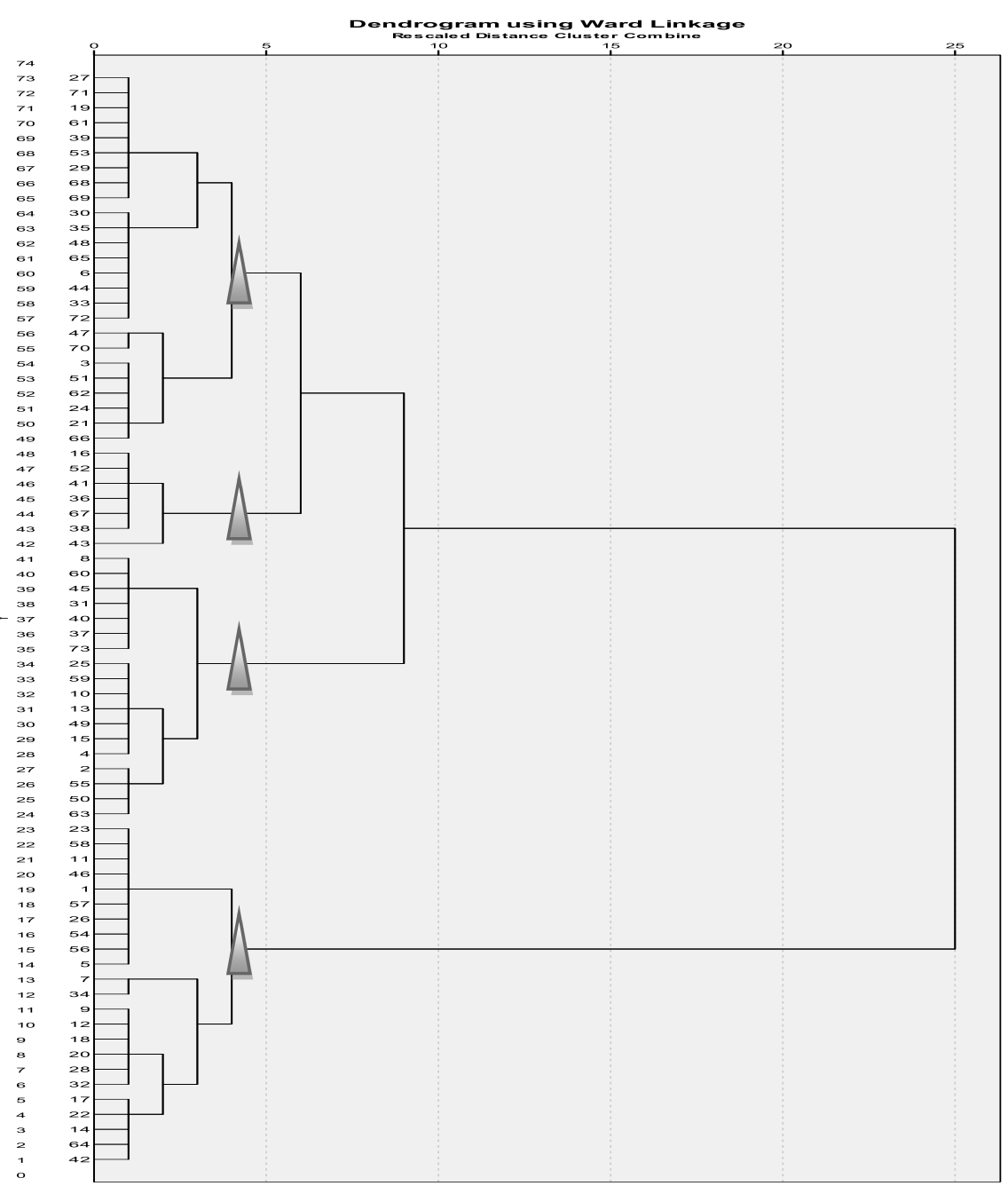

Gambar 3. Output dendogram

Berdasarkan Gambar 3, dapat dilihat bahwa dua tahap terakhir dari dendogram memiliki jarak paling besar. Untuk mendapatkan cluster yang memiliki kemiripan paling dekat, maka jarak yang dipilih adalah yang memiliki jarak paling kecil. Dari Gambar tersebut maka dapat dipilih 4 cluster yang berada pada rentang jarak 3-5. Dari keempat cluster tersebut didapatkan masing-masing kelompok yang memiliki kemiripan berdasarkan variabel usia, status pernikahan, tingkat pendidikan, rata-rata pendapatan dan pengeluaran per bulan serta kesan terhadap Beras Analog. Berikut adalah hasil analisis hierarki cluster yang terbagi menjadi 4 cluster (Tabel 9): 
Tabel 9. Hasil analisis hierarki cluster

\begin{tabular}{|c|c|c|}
\hline \multirow[b]{2}{*}{ Variabel } & \multicolumn{2}{|c|}{ Cluster } \\
\hline & 1 & 2 \\
\hline Usia & 21-30 tahun & 31-40 tahun \\
\hline Status Pernikahan & Belum Menikah & Menikah \\
\hline Tingkat Pendidikan & S1 & Diploma \\
\hline Rata-Rata Pendapatan & Rp 1.500.001-Rp 3.000.000 & Rp 3.000.001-Rp 4.500.000 \\
\hline Rata-Rata Pengeluaran & Rp 1.500.001-Rp 3.000.000 & Rp 3.000.001-Rp 4.500.000 \\
\hline Kesan & Cukup & Cukup \\
\hline \multirow[t]{2}{*}{ \%tase } & $32 \%$ & $25 \%$ \\
\hline & \multicolumn{2}{|c|}{ Cluster } \\
\hline Variabel & 3 & 4 \\
\hline Usia & $31-40$ tahun & 41-50 tahun \\
\hline Status Pernikahan & Menikah & Menikah \\
\hline Tingkat Pendidikan & S1 & S2 \\
\hline Rata-Rata Pendapatan & Rp 4.500.001-Rp 6.000.000 & Rp 4.500.001-Rp 6.000.000 \\
\hline Rata-Rata Pengeluaran & Rp 4.500.001-Rp 6.000.000 & Rp 3.000.001-Rp 4.500.000 \\
\hline Kesan & Suka & Suka \\
\hline \%tase & $34 \%$ & $9 \%$ \\
\hline
\end{tabular}

Sumber: Data Primer, diolah (2013)

\section{III.5 Analisis biplot}

Berdasarkan hasil analisis biplot yang dapat dilihat pada Gambar 4, atribut dapat dipetakan menjadi kwadran yang menggambarkan keragaan kategori dan atributnya. Pada peubah SP (sangat penting), garis vector terlihat cukup panjang karena di sekitar garis tersebut terdapat cukup banyak atribut yang diwakilkan, yaitu atribut Manfaat Kesehatan, Keamanan dikonsumsi dan Kandungan Nutrisi. Sedangkan untuk atribut Promosi dan Daya Tahan produk terdapat pada peubah P (penting).

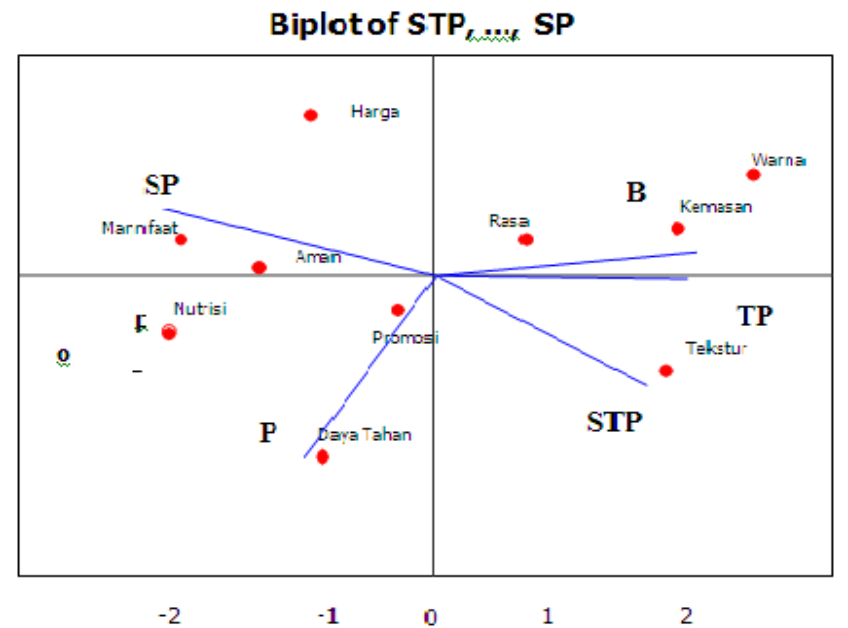

Gambar 4. Hasil biplot preferensi responden terhadap atribut Beras Analog

Selain itu melalui analisis Biplot dapat diketahui pula hubungan (korelasi) antar peubah (Gambar 5). Hubungan (korelasi) antar peubah dijelaskan dengan besarnya sudut yang terbentuk dari dua buah garis atribut. Semakin lancip sudut $\left(<90^{\circ}\right)$ yang 
terbentuk dari dua buah garis atribut, maka nilai korelasinya semakin besar (korelasi positif), sedangkan semakin tumpul sudutnya $\left(>90^{\circ}\right.$ ) yang terbentuk dari dua buah garis atribut, maka nilai korelasinya semakin kecil (negatif). Dua buah garis atribut yang membentuk sudut siku-siku $\left(90^{\circ}\right)$ maka tidak ada korelasi antara kedua atribut tersebut.

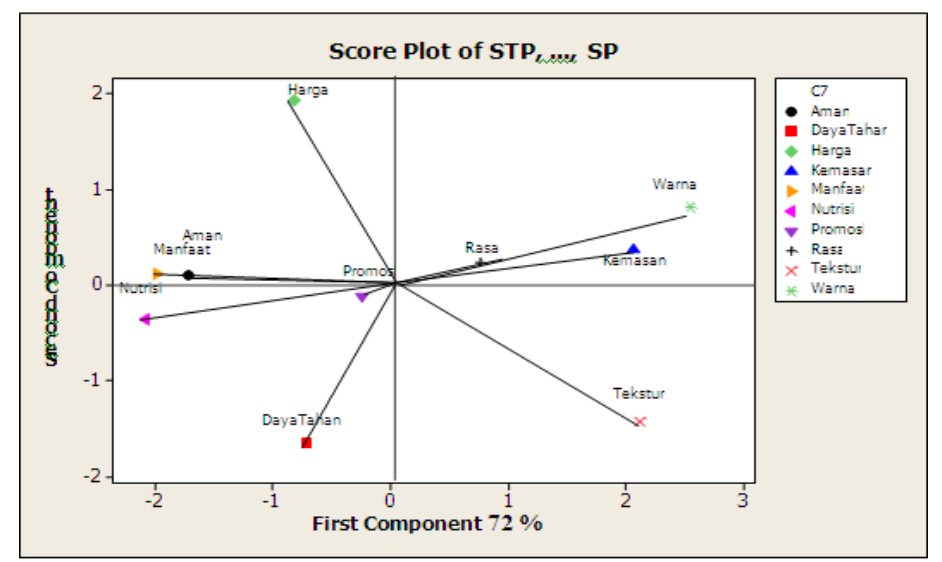

Gambar 5. Hasil biplot keragaman atribut produk Beras Analog

Pada Gambar 5 terlihat atribut nutrisi berkorelasi positif dengan atribut manfaat dan keamanan di konsumsi. Hal ini dapat diinterpretasikan bahwa semakin kaya nutrisi yang terkandung dalam suatu produk, semakin banyak manfaat kesehatan yang dapat diperoleh sehingga produk tersebut aman untuk dikonsumsi. Informasi lain yang didapat pada analisis Biplot ini adalah keragaman yang diterangkan oleh sumbu $x$ sebesar $72 \%$ dan sumbu y sebesar $15,6 \%$ sehingga secara keseluruhan keragaman yang diterangkan oleh kedua sumbu ini sebesar $87,6 \%$. Keragaman peubah (atribut) digambarkan dari panjang vector masing-masing atribut. Semakin panjang vektor suatu atribut, maka keragaman atribut semakin tinggi, begitu juga sebaliknya. Pada Gambar 5 terlihat bahwa atribut harga, warna dan tekstur memiliki vektor yang lebih panjang dibandingkan dengan vector lainnya. Nilai keragaman ini menunjukkan bahwa persepsi responden terhadap dua atribut tersebut lebih beragam dibandingkan atribut-atribut lainnya

\section{III.6 Strategi pemasaran}

Kotler dan Armstrong (2008) menjelaskan bahwa seluruh strategi pemasaran dibangun berdasarkan STP, Yaitu Segmentation (segmentasi), Targetting (penentuan target pasar), dan Positioning (penentuan posisi):

A. Segmentasi pasar (segmentation) Beras Analog

Menurut Setiadi (2008), segmentasi pasar adalah proses menempatkan konsumen dalam subkelompok di pasar produk, sehingga para pembeli memiliki tanggapan yang hampir sama dengan strategi pemasaran dalam penentuan posisi perusahaan. Berdasarkan analisis hierarki cluster, maka dapat dilakukan analisis segmentasi pasar yang diperoleh berdasarkan dua cluster dimana cluster 1 sebesar $32 \%$, cluster 2 sebesar $25 \%$, cluster 3 sebesar $34 \%$ dan cluster 4 sebesar $9 \%$. Dengan karakteristik untuk masing-masing cluster adalah sebagai berikut : 


\section{Cluster 1}

Merupakan responden berusia 21-30 tahun, belum menikah, tingkat pendidikan terakhir atau yang sedang dijalani yaitu S1, memiliki rata-rata pendapatan dan pengeluaran per bulan $\mathrm{Rp} 1.500 .000-\mathrm{Rp} 3.000 .000$ serta memiliki kesan cukup terhadap Beras Analog.

2. Cluster 2

Merupakan responden berusia 31-40 tahun, menikah, tingkat pendidikan terakhir atau yang sedang dijalani yaitu diploma, memiliki rata-rata pendapatan dan pengeluaran per bulan Rp 3.000.001-Rp 4.500.000 serta memliki kesan cukup terhadap Beras Analog.

3. Cluster 3

Merupakan responden berusia 31-40 tahun, menikah, tingkat pendidikan terakhir atau yang sedang dijalani yaitu S1, memiliki rata-rata pendapatan dan pengeluaran per bulan Rp 4.500.001-Rp 6.000.000 serta memliki kesan suka terhadap Beras Analog.

4. Cluster 4

Merupakan responden berusia 41-50 tahun, menikah, tingkat pendidikan terakhir atau yang sedang dijalani yaitu S2, memiliki rata-rata pendapatan dan per bulan $\mathrm{Rp}$ 4.500.001-Rp 6.000.000 dan rata-rata pengeluaran per bulan $\mathrm{Rp}$ 3.000.001-Rp 4.500.000 serta memliki kesan suka terhadap Beras Analog.

B. Penetapan pasar sasaran (targetting) Beras Analog

Menurut Umar (2000), terdapat tiga faktor untuk menetapkan pasar sasaran dalam rangka mengevaluasi dan memutuskan berapa segmen pasar yang akan dicakup serta segmen mana yang akan dilayani yaitu ukuran dan pertumbuhan segmen, kemenarikan struktural segmen serta sasaran dan sumber daya perusahaan.

Berdasarkan segmen yang telah didapatkan dari analisis hierarki cluster, jika dilihat berdasarkan ukuran segmen, ukuran dengan jumlah konsumen terbesar berada pada cluster 3 dengan jumlah konsumen sebesar 34\%. Berdasarkan kemenarikan ukuran segmen, cluster 1 dan cluster 2 belum menarik dari sisi profitabilitasnya. Hal ini dapat dilihat dari variabel kesan dimana cluster 1 dan 2 hanya mempunyai kesan cukup terhadap Beras Analog. Padahal variabel kesan suka sangat mempengaruhi daya tarik segmen yang positif untuk jangka panjang. Oleh karena itu penetapan target sasaran harus mengacu pada konsumen yang menyatakan kesukaannya pada Beras Analog.

F-Technopark IPB selaku pihak produsen Beras Analog harus mempertimbangkan sasaran dan sumber dayanya dalam kaitan dengan segmen pasar. Walau ada segmen yang bagus, akan tetapi dapat ditolak jika tidak prospektif dalam jangka panjang serta harus mempertimbangkan kemampuan dalam menyediakan sumber dayanya. Berdasarkan hasil wawancara, saat ini F-Tehncopark masih minim dalam ketersediaan sumber daya. Jika ingin mencakup lebih dari satu segmen maka diperlukan sumber daya yang besar untuk menjangkaunya. Meskipun cluster 4 mempunyai kesan suka, tapi persentase segmennya hanya 9\%, Oleh karena itu, cluster 3 merupakan pilihan tepat untuk di tetapkan sebagai pasar sasaran dengan karateristik responden yaitu berusia 31-40 tahun, menikah, tingkat pendidikan 
terakhir atau yang sedang dijalani yaitu S1, memiliki rata-rata pendapatan dan pengeluaran per bulan $\mathrm{Rp} 4.500 .000-\mathrm{Rp} 6.000 .000$ serta memiliki kesan suka terhadap Beras Analog.

C. Perumusan positioning Beras Analog

Berdasarkan penelitian yang telah dilakukan melalui penyebaran kuesioner preferensi derajat kepentingan atribut Beras Analog, pihak perusahaan dapat menyusun strategi pemasarannya dengan menonjolkan kepada pasar dimana letak perbedaannya dengan pesaing. Langkah ini diambil karena Beras Analog merupakan produk baru yang belum dikenal oleh masyarakat luas. Sehingga penting sekali bagi Beras Analog untuk menciptakan strategi pemasaran yang membedakan dirinya dengan produk pesaing.

Rumusan strategi pemasaran yang menonjolkan perbedaan dengan pesaing harus dibuat berdasarkan atribut yang dianggap sangat penting oleh konsumen. Atribut-atribut yang dianggap sangat penting dapat menjadi tolak ukur perumusan positioning Beras Analog. Berdasarkan hasil analisa yang telah didapat, maka pihak perusahaan dapat membuat perumusan positioning sebagai berikut:

"Beras Analog merupakan beras alternatif non padi yang aman dikonsumsi karena mengandung lebih banyak nutrisi dan bermanfaat untuk kesehatan". Adapun tagline yang dapat diberikan untuk Beras Analog antara lain: (1) "Beras Analog, Beras Sehat kaya Nutrisi" (2) "Analog rice, My Rice My Healthy".

\section{Kesimpulan}

Berdasarkan hasil penelitian yang telah dilakukan, kesimpulan yang dapat diambil dari penelitian ini adalah berdasarkan karateristik konsumen dapat diketahui bahwa sebagian besar konsumen berjenis kelamin perempuan dengan kelompok usia 31-40 tahun dan dengan status menikah. Tingkat pendidikan terakhir atau yang sedang dijalani adalah S1 dengan klasifikasi pekerjaan employee (pegawai), status pekerjaan sebagai pegawai swasta, dan memiliki profesi sebagai ibu rumah tangga dengan ratarata pendapatan per bulannya $\mathrm{Rp}$ 4.500.001-Rp 6.000.000. Adapun rata-rata pengeluaran konsumen per bulan adalah $\mathrm{Rp} 3.000 .000-\mathrm{Rp} 4.500 .000$. Hobi sebagian besar konsumen Beras Analog adalah jalan-jalan.

Berdasarkan persepsi konsumen diketahui bahwa mayoritas konsumen menyatakan kesan suka terhadap Beras Analog dengan penilaian suka pada rasa, aroma, teksur dan bentuk serta penilaian cukup pada warna. Tipe konsumsi yang cocok untuk Beras Analog adalah sebagai makanan selingan (kuliner). Bahan kemasan yang disukai sebagian besar konsumen Beras Analog adalah kemasan Standing Pouch dengan ukuran kemasan 800 gram serta Informasi yang dibutuhkan yang harus tertera pada kemasan adalah informasi nilai gizi. Lokasi pemasaran yang tepat untuk Beras Analog kedepannya adalah melalui pasar modern dengan bentuk promosi melalui iklan di televisi. Kisaran harga per packnya untuk Beras Analog adalah Rp 23.000 per 800 gram. Berdasarkan semua penilaian konsumen, sebagian besar konsumen berminat untuk mengkonsumsi kembali Beras Analog kedepannya. Pada hasil tabulasi silang, terdapat hubungan yang signifikan antara kesan dengan usia, status pernikahan, pendidikan, pendapatan dan pengeluaran serta minat mengkonsumsi kembali dan tipe konsumsi. Berdasarkan banyaknya jumlah responden yang menyukai dan berminat untuk 
mengkonsumsi kembali Beras Analog, maka dapat disimpulkan persepsi konsumen terhadap produk ini baik.

Berdasarkan Analisis Cluster dengan menggunakan Hierarki Cluster dapat diketahui bahwa jumlah segmen yang dapat dibentuk berdasarkan karateristik demografi konsumen yang signifikan pada hasil tabulasi silang (usia, status pernikahan, pendidikan, pendapatan dan pengeluaran) dan kesan adalah berjumlah empat segmen. Profil target pasar yang dipilih adalah yang memiliki persentase terbesar dan memiliki kesan "suka" sehingga cluster (segmen) yang terpilih yaitu cluster 3 dengan karateristik konsumen berusia 31-40 tahun, menikah, tingkat pendidikan terakhir atau yang sedang dijalani yaitu S1, memiliki rata-rata pendapatan dan pengeluaran per bulan Rp 4.500.001 - Rp 6.000.000. Berdasarkan Analisis Biplot, dapat diketahui bahwa posisi atribut yang berada pada derajat kepentingan sangat penting adalah atribut manfaat kesehatan, kandungan nutrisi dan keamanan dikonsumsi sehingga perumusan positioning yang dapat disusun adalah "Beras Analog merupakan beras alternatif non padi yang aman dikonsumsi karena mengandung lebih banyak nutrisi dan bermanfaat untuk kesehatan".

\section{Daftar Pustaka}

Andrianto MS, S Budijanto, dan D Indrawan 2013. Pendekatan "In Process Innovation Strategy" Melalui Analisis Faktor Pembelian Dan Potensi Pasar Pangan Alternatif Pada Target Pasar Remaja: Studi Kasus Pengembangan Invensi Beras Analog (Artificial Rice). Di dalam: Illah S, Said EG, Indrasti NS, Djamaran I, Joewono HH, Santosa K, Suprihatin, Syamsu K, editor. Prosiding Konferensi Nasional dan Technopreneruship: Mendidik dan Menciptakan Inovator dan Technopreneur; 2013 Feb 18-19; Bogor, Indonesia. Bogor (ID): RAMP IPB. HIm 295-305.

Budijanto S. 2012. Beras Analog "Product Vehicle" Diversifikasi Pangan Untuk Memperkokoh Ketahanan Pangan Nasional. Bogor (ID): F-Technopark Institut Pertanian Bogor.

F-Technopark Institut Pertanian Bogor. 2013. Data Penjualan Beras Analog Periode November-Januari 2012. Bogor (ID): F-Tehncopark Institut Pertanian Bogor.

Kotler P, dan Armstrong G. 2008. Prinsip-Prinsip Pemasaran. Ed ke-12. Jakarta (ID): Erlangga.

Mattjik AA, dan Sumertajaya IM. 2011. Sidik Peubah Ganda dengan menggunakan SAS. Bogor (ID): Departemen Statistika FMIPA IPB.

Malhotra NK. 2006. Riset Pemasaran Pendekatan Terapan. Jakarta (ID): PT Indeks Kelompok Gramedia.

Setiadi JN. 2008. Perilaku Konsumen: Konsep dan Implikasi untuk Strategi dan Penelitian Pemasaran. Jakarta (ID): Kencana Prenada Media Group.

Simamora. 2005. Analisis Multivariat Pemasaran. Jakarta (ID): PT.Gramedia Pustaka Utama.

Suliyanto. 2005. Analisis Data dalam Aplikasi Pemasaran. Bogor (ID): Ghalia.

Tempo. 2013. Antisipasi Krisis Pangan, Beras Analog Disiapkan. [Internet]. [diunduh 2013 April]. Terdapat pada: http://www.tempo.co/read/news/2013/03/26/ 090469444/Antisipasi-Krisis-Pangan-Beras-Analog-Disiapkan.

Umar H. 2000. Riset Pemasaran dan Perilaku Konsumen. Jakarta (ID): Gramedia. 